\title{
The Timing and Specificity of Prenatal Immune Risk Factors for Autism Modeled in the Mouse and Relevance to Schizophrenia
}

\author{
Gráinne M. McAlonana-c Qi Li ${ }^{\mathrm{a}, \mathrm{c}}$ Charlton Cheung ${ }^{\mathrm{a}}$ \\ ${ }^{a}$ Department of Psychiatry, ${ }^{b}$ State Key Laboratory for Brain and Cognitive Sciences, 'Centre for Reproduction, \\ Development and Growth, The University of Hong Kong, Hong Kong, SAR, China
}

\section{Key Words}

Autism • Mouse model $\cdot$ Prenatal infection · Inflammation • Schizophrenia $\cdot$ Infection • Pregnancy

\begin{abstract}
Autism is a highly heritable condition, but there is strong epidemiological evidence that environmental factors, especially prenatal exposure to immune challenge, contribute to it. This evidence is largely indirect, and experimental testing is necessary to directly examine causal mechanisms. Mouse models reveal that prenatal immune perturbation disrupts postnatal brain maturation with alterations in gene and protein expression, neurotransmitter function, brain structure and behavioral indices reminiscent of, but not specific to, autism. This likely reflects a neurodevelopmental spectrum in which autism and schizophrenia share numerous genetic and environmental risk factors for difficulties in social interaction, communication, emotion processing and executive function. Recent epidemiological studies find that early rather than late pregnancy infection confers the greater risk of schizophrenia. The autism literature is more limited, but exposures in the 2 nd half of pregnancy may be important. Mouse models of prenatal immune challenge help dissect these observations and show some common consequences of early and late gestational exposures, as well as distinct
\end{abstract}

ramifications potentially relevant to schizophrenia and autism. Although nonspecificity of immune-stimulated mouse models could be considered a disadvantage, we propose a broadened perspective, exploiting the possibility that advances made investigating a target condition can contribute towards the understanding of related conditions.

Copyright $\odot 2010$ S. Karger AG, Basel

\section{Introduction}

Autism is a highly genetic neurodevelopmental disorder [1-7], characterized by a triad of repetitive and stereotypic behaviors, impaired communication and marked difficulties in social reciprocity $[8,9]$. Postmortem studies date the onset of neuropathology as early as fetal life $[10,11]$ and there is increasing evidence that this results in postnatal anatomical abnormalities in fronto-temporo-parietal cortices, the limbic system and cerebellum [12-18], and white matter abnormalities [14, 19], which may contribute to functional asynchrony in BOLD (blood oxygenation level-dependent) signals reported during higher-order cognitive processing autism [20-24].

The etiology of autism spectrum disorders remains mysterious. Although autism is a highly heritable condition, genetics alone cannot fully account for the condi-

\section{KARGER \\ Fax +41613061234 \\ E-Mail karger@karger.ch}

www.karger.com
(C) 2010 S. Karger AG, Basel

$1424-862 X / 10 / 0182-0129 \$ 26.00 / 0$

Accessible online at:

www.karger.com/nsg
Dr. Gráinne M. McAlonan

Department of Psychiatry

The University of Hong Kong

Hong Kong, SAR (China)

Tel. +852 2255 4486, Fax +852 2855 1345, E-Mail mcalonan@ @kucc.hku.hk 
tion. There is strong evidence that environmental factors, especially prenatal life exposures, also contribute to autism [25-29]. Disentangling the effects of environment and genes in clinical populations is challenging. Increasingly, the need for direct experimental testing of causal mechanisms is appreciated. This can be achieved through mouse models, with the caveat that no mouse model can capture the uniquely human aspects of autism. However, the mouse system readily gives access to basic mechanisms underlying complex behaviors. Rodent biology is remarkably similar to man and, with a lifespan of around 2 years, developmental and maturational processes can be compressed in vivo. This facilitates the rapid translation of successful basic science research in the laboratory to clinical application.

Even though superficially quite distinct, autism spectrum conditions have a number of points of overlap with other neurodevelopmental conditions, such as schizophrenia. People with autism spectrum have a strong family history of schizophrenia and bipolar disorder [30], and have alterations in the same set of genes [31,32]. Neuroanatomically, both conditions lead to abnormalities in frontostriatal systems $[13,14,27-29,33-38]$ and individuals with autism spectrum may even suffer from psychosis [39]. Asperger's syndrome is associated with higher scores on measures of paranoia than is typical [40]; 'negative' symptoms reminiscent of schizophrenia in people with Asperger's syndrome partly respond to the antipsychotic risperidone [41], and antipsychotics can improve some symptoms of autism $[42,43]$.

Social interaction, communication, emotion processing and executive function abilities are disrupted by both conditions; both involve unusual responsiveness to the environment and impaired stimulus filtering (measured by a failure of sensorimotor gating in the prepulse inhibition of startle paradigm) [17, 44-46]. Indeed, autism was originally referred to as a 'schizophrenic syndrome of childhood' or 'childhood psychosis', and has been suggested to lie on the same spectrum as schizophrenia [34, 47]. One way to conceptualize this is to consider that it is not the autistic or schizophrenic condition itself which is inherited, but rather altered neurodevelopment [48]. However, others take an alternative position and argue that schizophrenia and autism are 'diametrically opposite' [49].

Therefore the study of the neurobiology of behaviors relevant to autism using the mouse is necessarily limited by specificity, making it unlikely that mouse models generated will apply only to autism. As a result, the choice of behavioral paradigms which examine face validity of mouse models becomes problematic. Most test procedures which can be interpreted as relevant to autism, are also relevant to schizophrenia. For example, impaired sensorimotor gating, measured in prepulse inhibition of startle (PPI) procedures, has been reliably documented in schizophrenia $[45,46]$. Initial study of sensorimotor gating in a broad spectrum of participants with autism returned inconclusive findings [50]. However, in a more homogeneous sample of adult men with Asperger's syndrome, we observed sensorimotor gating anomalies [17], and others have replicated this finding in individuals with high functioning autism [44].

A number of conditions involving frontostriatal system pathology are known to disrupt PPI, including obsessive compulsive disorder [51]. Nevertheless, this paradigm has come to be included as a core component of any battery testing autistic-like phenotype in mouse models. The advantage is that PPI is readily observed in all mammals under similar stimulus parameters. Such cross-species utility makes PPI among the most useful of translational tasks for animal models of neurodevelopmental disorders [52-55]. Additional behavioral phenotype measures which have face validity for autism spectrum may also apply more generally to neurodevelopmental disorders. A battery of behavioral tasks relevant to autism has been comprehensively documented [56, 57]. These include probes for various social behaviors and response perseveration, which although altered in autism [58] are also affected by other conditions, including schizophrenia $[59,60]$. This lack of specificity can be seen as a disadvantage, but perhaps more realistically it demands a broadened perspective, open to the possibility that advances made investigating a target condition can contribute towards understanding related conditions.

\section{Prenatal Immune Activation Alters Postnatal Neurodevelopment}

Maternal infection during prenatal life is implicated in the etiology of both autism and schizophrenia [29, 61-67] and maternal viral infection has been suggested to be 'the principal nongenetic cause of autism' [68]. That maternal infection can precipitate neurodevelopmental sequelae relevant to autism or schizophrenia has been directly tested using rodent models of maternal immune activation (MIA) with respiratory infection, borna virus and influenza [69-75]. 


\section{Influenza}

The Fatemi group has contributed a rich body of work examining the consequences of prenatal infection with influenza virus using the mouse. Prenatal influenza infection has been reported to impair PPI in the offspring, and cause deficits in open field, novel object exploration and social interaction [76]. Influenza infection of pregnant mice also interrupts migration and causes loss of cerebellar Purkinje cells in the offspring [77], a hallmark of autism [78] which is also observed in schizophrenia [79]. Prenatal exposure has a considerable and widespread impact on the expression of key regulatory proteins in brain. It has been shown to decrease the expression of reelin in the postnatal hippocampus [80]. Reelin is a neuroregulatory protein of critical importance during the development of the central nervous system [71] and its expression is disrupted in autism [81-84] and other neurodevelopmental conditions, including schizophrenia and bipolar disorder $[79,81,85]$. Changes in expression of a number of genes coding for structural and functional proteins are triggered by prenatal influenza exposure. Exposure to influenza on gestation day (GD) 9 modifies expression of chaperones, HSC70, bicaudal D, aquaporin 4 , carbonic anhydrase 3 , glycine receptor, norepinephrine transporter and myelin basic protein [86]. Later exposure to influenza on GD16 also alters myelin basic protein, expression of other myelination genes (e.g. Mbp, Mag, and Plp1) and fractional anisotropy (FA) measures, a diffusion tensor MRI marker of white matter integrity [87]. The importance of timing of prenatal exposure to postnatal outcomes is discussed further below.

\section{Polyinosinic:Polycytidylic Acid}

A complementary collection of experiments has been designed to show that many consequences of MIA are not pathogen-specific. For example the viral analogue polyinosinic:polycytidylic acid (PolyI:C) administered during pregnancy is sufficient to drive the MIA phenotype which encompasses a wide spectrum of behaviors including conditioning anomalies, impaired PPI and hypersensitivity to amphetamine challenge [88-98]. The brain structural basis of these behavioral abnormalities may involve white matter systems. Early prenatal exposure to PolyI:C, at the time when oligodendrocytes are generated in the ganglionic eminence (GD9.5), delays myelination processes during postnatal brain maturation [99]. In our own studies, we found prenatal PolyI:C leads to wide-

Immune-Stimulated Mouse Models of Autism spread bidirectional changes in FA which were associated with concomitant alterations in the level of an immunohistochemical marker for oligodendrocytes (CNPase) [100].

\section{Interleukin-6}

In an elegant series of experiments, Smith et al. [101] isolated the cytokine interleukin-6 (IL-6) as a key mediator of the effects of PolyI:C. A single injection of IL-6 administered to pregnant mice on day 12.5 was sufficient to precipitate adult PPI and latent inhibition deficits usually consequent on PolyI:C exposure. Simultaneous injection of an anti-IL- 6 antibody prevented a wide range of behavioral deficits and gene expression changes caused by prenatal PolyI:C. Most convincingly, IL-6 knockout mice were resistant to the effects of MIA [101]. However, elevation of other cytokines, such as IL-2, in early life have also been shown to elicit behavioral changes, such as increased activity in open field and impaired acquisition of a conditioned eye-blink response [102].

IL-6 is now appreciated to have widespread effects on early neuronal differentiation. IL- 6 has been shown to support survival of basal forebrain cholinergic cells in culture and promote differentiation of tyrosine hydroxylase-positive catecholamine cells $[103,104]$. This is a striking observation because very recent investigation [105] has shown that, on GD18, choline acetyltransferase, a marker of cholinergic neurons, is increased in the basal forebrain of mice previously exposed to PolyI:C on day 12.5. IL-6 plays a major part in this effect as the same result is not seen in IL-6 knockout mice. In addition, PolyI:C administered on GD9 has been shown to increase the numbers of tyrosine hydroxylase-positive neurons in the dopamine-rich substantia nigra of the fetal mouse [106]. Furthermore, the projection pathways from these neuronal populations coincide with regions of increased fractional anisotropy (a measure of white matter microstructural integrity) in adult mice exposed to PolyI:C prenatally [100], suggesting that MIA via IL-6 has far-reaching effects on the development of major neurotransmitter circuits in the mouse brain.

Microglia produce IL- 6 and their activation in the fetal brain has been suggested to contribute to the action of maternal inflammation on brain development in the MIA model [105]. Microglia migrate to the mouse fetal brain in mid-gestation and at this time are found in the ganglionic eminence (containing the progenitor cells of caudate, putamen, amygdala) [107] and around the Cajal- 
Retzius cells, the reelin-producing cells which guide cortical organization. It is compelling that a rich density of IL-6R can be stained along the ganglionic eminence, where IL-6-producing microglial cells are in such abundance. The ganglionic eminence persists until term [108], making it potentially a target of IL-6-mediated effects on neuronal migration and differentiation throughout gestation. Evidence that the germinal matrix is especially vulnerable to inflammatory mediators comes from observations of subependymal cysts at the head of the caudate following congenital rubella infection [109]. Indeed, prenatal rubella infection is associated with autism, and subependymal cysts have been reported in children with autism who had congenital infection [67].

\section{Lipopolysaccharide}

Driving immune activation through the bacterial mimic, lipopolysaccharide triggers a postnatal phenotype change similar to that induced by viral-type response, including PPI deficits [110] and hypersensitivity to amphetamine challenge [111] in rats. Behavioral disruption in mice offspring exposed to maternal lipopolysaccharide on GD17 has also been reported [112]. Lipopolysaccharide administered to pregnant mice on day 15 of gestation caused elevated IL- 6 in maternal sera and in amniotic fluid [113], implying that bacterial and viral challenges may trigger similar changes in cytokine response in the pregnant mouse. Resisting this position are findings that both the timing of MIA and the viral or bacterial-like nature of the challenge have distinct repercussions on the phenotype, at least in the rat [111]. This will be discussed further below, but in general terms, the bulk of experimental work on rodents supplements clinical evidence of a role for the immune system in modifying the neurodevelopmental trajectory of vulnerable individuals [114-117].

\section{Maternal Anti-Fetal Brain Antibody}

Another piece of the puzzle surrounding early life immune mechanisms in autism has recently come to light. Some mothers of children with autism secrete antibodies for prenatally expressed brain antigens. These have been proposed to cross the placenta and modify brain development in the fetus, with persistent postnatal effects [118, 119]. Modeling this effect, serum from mothers with autistic children has been administered to pregnant mice.
Offspring born to mice exposed to the human sera showed increased activity in open field, greater anxiety and greater acoustic startle response in addition to altered sociability. This behavioral phenotype was accompanied by glial activation $[120,121]$, which has been reported in postmortem studies of both autism [117] and schizophrenia [122].

One criticism of this and other mouse models developed to understand autism is the nonspecific nature of the behavioral changes described, and whether these truly map to the human condition. Certainly, the mouse can never replicate uniquely human attributes, but much behavior does have cross-species analogy. To a large degree the problem of nonspecificity is compounded by the fact that autism is a constellation of features, none of which is itself specific to the autistic spectrum. To address this, the pregnancy antibody challenge has also been given to nonhuman primates, and offspring born to rhesus monkeys exposed to sera from mothers of children with autism showed increased repetitive and stereotypic behaviors [118]. In that study, the serum administered was collected from the mothers of more than 1 child with autism. There is potential for pregnant mothers to become sensitized to fetal blood cells during gestation [123], but the likelihood that a mother produces antibodies against fetal leukocyte antigens increases with parity [124]. IL-6, produced by T helper 2 cell populations, promotes B cell maturation and antibody production. Moreover, progesterone at the fetalmaternal interface promotes $\mathrm{TH} 2$ responses, as does estrogen [121]. Thereby mechanisms which elevate IL-6 may also cause increased antibody production.

\section{Postnatal Phenotype Depends upon the Timing of Prenatal Exposure}

While MIA cannot be said to be specific to autism or schizophrenia, it is clear that the precise timing of MIA does affect the phenotypic outcome on a number of dimensions. From an epidemiological perspective, the data obtained by previous retrospective research implicated mid-pregnancy as a window of vulnerability for infection-induced schizophrenia risk [125-128]. This early work has been superseded by studies using serological markers to indicate maternal infection in the early stages of pregnancy (i.e. in the 1st trimester of human pregnancy) carries the greatest risk [62]. The possible influence of timing of infection on risk of autism has not been examined quite so comprehensively, but there are clues. Postmortem histopathological investigation points to a failure in neuronal maturation before $30-32$ weeks gestation $[10,129,130]$. This is consistent with reports of a higher 
Table 1. Postnatal effects of immune stimulation at different time points during mouse gestation

\begin{tabular}{|c|c|c|c|c|c|c|c|c|c|c|c|}
\hline & Schiz & Pol & Flu & IL-6* & POL & IgG & Flu & LPS & POL & ASD & References \\
\hline Gestation day in mouse & & 9 & 9 & 12 & 12 or 13 & 13 to 18 & 16 or 18 & 817 & 17 & & \\
\hline PPI & $\downarrow$ & $\downarrow$ & $\downarrow$ & $\downarrow$ & $\downarrow$ & & & & $\leftrightarrow$ & $\leftrightarrow / \downarrow$ & $17,46,50,76,88,95,101$ \\
\hline Open field & $\uparrow$ & $\downarrow$ & $\downarrow$ & $\downarrow$ & & $\uparrow$ & & & $\leftrightarrow$ & $\downarrow$ & $76,93,101,120,150$ \\
\hline Novel object exploration & $\leftrightarrow$ & & & & & & & $\uparrow$ & & $\downarrow$ & $112,150,151$ \\
\hline \multicolumn{12}{|l|}{ Perseveration (resistance } \\
\hline to rule reversal) & $\uparrow$ & $\leftrightarrow$ & & & & & & & $\uparrow$ & $\uparrow$ & $58,59,93$ \\
\hline Latent inhibition & $\downarrow$ & $\downarrow$ & & $\downarrow$ & & & & & $\leftrightarrow / \uparrow$ & & $90,91,101,155,156$ \\
\hline Passive avoidance & $\downarrow$ & & & & & & & $\downarrow$ & & & 112,157 \\
\hline Antipsychotic response & $\uparrow$ & & $\uparrow$ & & & & & & & $\uparrow$ & $37,43,76,158$ \\
\hline \multicolumn{12}{|l|}{ Myelination processes/ } \\
\hline gene/protein expression & $\downarrow$ & $\downarrow$ & $\downarrow$ & & & $\downarrow$ & $\downarrow$ & & & $\downarrow$ & $86,87,99,100,159-161$ \\
\hline Glial activation & $\uparrow$ & & & & $\uparrow$ & $\uparrow$ & & & & $\uparrow$ & $105,117,120,121$ \\
\hline Fractional anisotropy & $\downarrow$ & $\uparrow$ & $\uparrow$ & & & $\downarrow$ & $\downarrow$ & & $\downarrow$ & $\uparrow$ & $19,35,87,100$ \\
\hline Lateral ventricles & $\uparrow$ & $\uparrow$ & $\downarrow$ & & & $\leftrightarrow$ & $\leftrightarrow$ & $\leftrightarrow$ & $\downarrow$ & $\downarrow$ & $36,71,88,112,120,141,148$ \\
\hline
\end{tabular}

* Direct effect of IL- 6 or inferred from neutralization or knockout models. $\uparrow=$ Enhanced or improved; $\downarrow=$ reduced; $\uparrow=$ bidirectional findings; $\leftrightarrow$ = unchanged; blank = undetermined; Schiz = schizophrenia; ASD = autism spectrum; POL = PolyI:C; Flu = influenza; LPS = lipopolysaccharide; IgG = sera from human mothers of autistic children. This table is not exhaustive, please see text for further details.

incidence of prenatal stressors during 21-32 weeks gestation in autism [131] and a greater increase in risk of autism following exposure to very severe stress in later rather than early pregnancy [132]. Complementing studies pointing to a 2 nd trimester or later window for autism is data showing that mothers diagnosed with asthma or allergies in 2nd trimester have an increased risk of having a child with autism. Of note, Zimmerman et al. [119] have described antibody response in mothers with autistic children as directed against fetal (GD18, equivalent to human 2 nd trimester), but not early postnatal (day 8 ), rat brain protein. Still, the story is likely to be complicated, and a recent investigation of maternal infection requiring hospitalization during pregnancy found risk of autism in children born to these mothers was increased by viral infection in the 1st trimester, and by bacterial infection in the 2nd trimester [133]. However, evidence from clinical studies can be difficult to interpret and as the authors of the latter study acknowledge, their data excluded the likely large number of infections not requiring hospitalization. They suggested the work be considered exploratory and numerous possible confounding factors, such as the severity of the infection, general immune status of the mother, comorbid conditions, comorbid infections and drug treatment, could have influenced the results.

In experimental mouse models, exposure to early and late gestational windows has been examined (see table 1 for summary of the main findings). GD9 and GD17 in the mouse approximate to the end of the middle of the 1st and 2nd trimester of human pregnancy respectively [134, 135]. In studies using PolyI:C, early maternal immune activation on GD9 impairs prepulse inhibition and causes hypersensitivity to amphetamine challenge in the adult offspring [90, 91]. While this behavioral profile does translate well to schizophrenia [45, 46, 136, 137], deficits in PPI are found in the autism spectrum $[17,44]$ and autism is also complicated by an overactive dopamine system $[138,139]$. In contrast, GD17 exposed offspring have minimal PPI deficits [88] and are resistant to acquiring a rule reversal [93]. This phenotype is pertinent to autism, given that PPI deficits are not always observed [50] and a significant resistance to change is a feature of many in the spectrum. That said, strong resistance to change, or 'in- 
sistence in sameness', may characterize a discrete subgroup of individuals within the autism spectrum, independent of language, gender, age, IQ and other symptom domains [140]. Thus, the heterogenic effects of different time points of exposure may mirror the heterogenic nature of the autism spectrum.

Meyer et al. [93] have carefully dissected the fetal brain response to maternal immune challenge at early and late pregnancy time-points. At $3 \mathrm{~h}$ after treatment, maternal immune stimulation on GD9 led to a large increase in IL-6 and decrease in IL-10 in the fetal brain. In contrast, GD17 exposure decreased IL- 6 and increased IL-10 in the fetal brain at $3 \mathrm{~h}$ after treatment. However, at $6 \mathrm{~h}$ after treatment, IL- 6 was elevated in the fetal brain regardless of the time-point of exposure. In the same study, Meyer's team showed that reelin expression in the hippocampus of 24-day-old offspring was decreased more following GD9 exposure to PolyI:C than later exposure. Thus, the consequences of PolyI:C exposure on reelin on GD9 appear to coincide with influenza administered on the same timepoint, although unlike the immediate response to PolyI:C, the immune response to influenza infection would be expected to peak a few days after the acute event [76].

The consequences of prenatal exposure to human influenza virus have also been examined at 2 different time-points in mice. Exposure on GD18 alters the expression of genes associated with both schizophrenia and autism such as Sema3a, Trfr2 and Vldlr [141]. Influenza exposure on GD9 perturbates reelin and GFAP protein levels in the offspring $[80,142]$. Either GD9 or GD18 exposure to influenza virus causes upregulation of the transcription factor Foxp2 [141, 143], previously associated with schizophrenia [144] and autism [145]. Thus, there is some degree of overlap in both fetal brain immune response and subsequent gene expression following influenza MIA. However, there are also quite distinct responses to the same challenge at different time-points which may respectively contribute to the common and divergent postnatal behavioral phenotypes reported.

Complicating this story is imaging data showing that mice exposed to a maternal immune challenge early, but not later, in prenatal life develop ventriculomegaly [88]. Increased lateral ventricular volumes is the most consistently reported finding in schizophrenia brain imaging literature [146, 147], but is not associated with autism. In contrast, smaller lateral ventricular size has been reported in autism [148], and mice exposed to PolyI:C in late pregnancy have decreased CSF volumes in the lateral ventricles [88]. The data from experimental influenza exposure is partly conflicting. By adulthood, mice exposed to influenza virus on GD9 have decreased lateral ventricle volume and macrocephaly, as reported in autism [71]. A later exposure to influenza on GD18 caused brain atrophy and no change in ventricular volume [141]. One possible reason for this divergence in results following PolyI:C or influenza exposure may reside in the timing of cytokine elevation. PolyI:C triggers an acute, but shortlived rise in cytokine production within a few hours of injection. Influenza aerosol contamination takes a few days to generate a peak response; therefore, influenza exposure on GD9 is perhaps better compared to the effects of PolyI:C administration on GD12 [76]. Clearly, some effects of viral-like immune challenge in early or late pregnancy are dissociable and the impact of timing of prenatal immune challenge is not a simple matter of severity [97]. In terms of ventricular indices of global brain maturational differences, early or later immune activation may shift development along a path which is more 'schizophrenia-like' or more 'autism-like', respectively. However, the shared aspects of the early and late phenotype described in mouse models mirror well the many shared features of neurodevelopmental conditions such as autism and schizophrenia [31, 34, 47, 48].

The possible divergence of phenotype to either end of an autism-schizophrenia spectrum depending on the time-point of MIA is supported by evidence from studies looking at the time course of onset of postnatal abnormalities following early prenatal immune activation. Schizophrenia is characterized by a 'latent' phase of the disease in childhood, followed by prodromal symptoms in adolescence and postponement of full clinical presentation, usually until early adulthood. There is accumulating evidence that earlier exposure to PolyI:C indeed precipitates the fullest behavioral change only in adult offspring. Meyer et al. [94] have shown that GD9 exposure to PolyI:C leads to enhanced sensitivity to an amphetamine, but not MK801 challenge in open field in adolescence. By adulthood, MK801 triggered an enhanced response. Moreover, only in adulthood are immunoreactivity measures of tyrosine hydroxylase increased and D1R, and GluR1R immunoreactivity decreased in prenatal exposed mice $[94,95]$. In a subsequent longitudinal study, the latter group reported MIA induced age-dependent alterations in the number of midbrain dopamine cells and presynaptic dopaminergic markers in striatum [106]. This collection of studies, mapping dynamic changes in development and maturation of the neurotransmitter systems, including the dopamine system, may hold particular relevance to schizophrenia since the greatest changes appear in adulthood. There have been fewer lon- 
gitudinal studies of offspring of mice exposed in late pregnancy. Following influenza infection on GD18, relative to sham controls, offspring had increased cerebellar dopamine levels at birth and decreased serotonin levels on postnatal day 14 , but no differences in either transmitter by adulthood [149]. Clearly the consequences of prenatal immune challenge have complex effects on the precise phenotype of the offspring and on the postnatal time course of pathology.

\section{Conclusions}

Mouse model work provides direct experimental evidence that prenatal immune perturbation alters the postnatal developmental trajectory. The alterations in gene and protein expression, neurotransmitter function, brain structure and behavioral indices are strongly reminiscent of autism spectrum. However, the effects of prenatal immune activation are unlikely to be specific to the autism spectrum, and hold relevance to other neurodevelopmental conditions, particularly schizophrenia. This most likely reflects the complex nature of a neurodevelopmental spectrum which includes autism and schizophrenia $[31,34,48]$. Although important information has already been gleaned by modeling the mechanisms set in process by prenatal inflammatory risk factors in the mouse, much remains to be extracted from this line of enquiry. It is clear that these and other mouse models of autism hold considerable potential to guide prevention strategies and encourage design of novel interventions.

\section{References}

$>1$ Bailey A, Le Couteur A, Gottesman I, Bolton P, Simonoff E, Yuzda E, Rutter M: Autism as a strongly genetic disorder: evidence from a British twin study. Psychol Med 1995;25:6377.

-2 Gupta AR, State MW: Recent advances in the genetics of autism. Biol Psychiatry 2007;61: 429-437.

$>3$ Lamb JA, Moore J, Bailey A, Monaco AP: Autism: recent molecular genetic advances. Hum Mol Genet 2000;9:861-868.

$\checkmark 4$ Lamb JA, Parr JR, Bailey AJ, Monaco AP: Autism: in search of susceptibility genes. Neuromolecular Med 2002;2:11-28.

$\checkmark 5$ Monaco AP, Bailey AJ: Autism. The search for susceptibility genes. Lancet 2001; 358(Suppl):S3.

$\checkmark 6$ Ronald A, Happe F, Plomin R: Genetic research into autism. Science 2006;311:952, author reply 952 .

$>7$ Szatmari P, Jones MB, Zwaigenbaum L, MacLean JE: Genetics of autism: Overview and new directions. J Autism Dev Disord 1998;28:351-368.

$>8$ Baron-Cohen S: The cognitive neuroscience of autism. J Neurol Neurosurg Psychiatry 2004;75:945-948.

$>9$ Frith U, Happe F: Autism spectrum disorder. Curr Biol 2005;15:R786-R790.

10 Bauman M, Kemper TL: Histoanatomic observations of the brain in early infantile autism. Neurology 1985;35:866-874.

-11 Kemper TL, Bauman ML: Neuropathology of infantile autism. Mol Psychiatry 2002; 7(Suppl 2):S12-S13.

- 12 Brambilla P, Hardan A, di Nemi SU, Perez J, Soares JC, Barale F: Brain anatomy and development in autism: review of structural MRI studies. Brain Res Bull 2003;61:557569 .

Immune-Stimulated Mouse Models of Autism
13 Hallahan B, Daly EM, McAlonan G, Loth E, Toal F, O’Brien F, Robertson D, Hales S, Murphy C, Murphy KC, Murphy DG: Brain morphometry volume in autistic spectrum disorder: a magnetic resonance imaging study of adults. Psychol Med 2009;39:337-346.

14 McAlonan GM, Cheung C, Cheung V, Wong N, Suckling J, Chua SE: Differential effects on white-matter systems in high-functioning autism and Asperger's syndrome. Psychol Med 2009:1-9.

15 McAlonan GM, Cheung V, Cheung C, Chua SE, Murphy DG, Suckling J, Tai KS, Yip LK, Leung P, Ho TP: Mapping brain structure in attention deficit-hyperactivity disorder: a voxel-based MRI study of regional grey and white matter volume. Psychiatry Res 2007; 154:171-180.

16 McAlonan GM, Cheung V, Cheung C, Suckling J, Lam GY, Tai KS, Yip L, Murphy DG, Chua SE: Mapping the brain in autism. A voxel-based MRI study of volumetric differences and intercorrelations in autism. Brain 2005; 128:268-276.

17 McAlonan GM, Daly E, Kumari V, Critchley HD, van Amelsvoort T, Suckling J, Simmons A, Sigmundsson T, Greenwood K, Russell A, Schmitz N, Happe F, Howlin P, Murphy DG: Brain anatomy and sensorimotor gating in Asperger's syndrome. Brain 2002;125:15941606.

18 McAlonan GM, Suckling J, Wong N, Cheung V, Lienenkaemper N, Cheung C, Chua SE: Distinct patterns of grey matter abnormality in high-functioning autism and Asperger's syndrome. J Child Psychol Psychiatry 2008; 49:1287-1295.
19 Cheung C, Chua SE, Cheung V, Khong PL, Tai KS, Wong TKW, Ho TP, McAlonan GM: White matter fractional anisotrophy differences and correlates of diagnostic symptoms in autism. J Child Psychol Psychiatry 2009; 50:1102-1112.

20 Brambilla P, Hardan AY, di Nemi SU, Caverzasi E, Soares JC, Perez J, Barale F: The functional neuroanatomy of autism. Funct Neurol 2004; 19:9-17.

21 Just MA, Cherkassky VL, Keller TA, Kana RK, Minshew NJ: Functional and anatomical cortical underconnectivity in autism: evidence from an FMRI study of an executive function task and corpus callosum morphometry. Cereb Cortex 2007;17:951-961.

-22 Just MA, Cherkassky VL, Keller TA, Minshew NJ: Cortical activation and synchronization during sentence comprehension in high-functioning autism: evidence of underconnectivity. Brain 2004; 127:1811-1821.

23 Koshino H, Carpenter PA, Minshew NJ, Cherkassky VL, Keller TA, Just MA: Functional connectivity in an fMRI working memory task in high-functioning autism. Neuroimage 2005;24:810-821.

24 Critchley HD, Daly EM, Bullmore ET, Williams SC, Van Amelsvoort T, Robertson DM, Rowe A, Phillips M, McAlonan G, Howlin P, Murphy DG: The functional neuroanatomy of social behaviour: changes in cerebral blood flow when people with autistic disorder process facial expressions. Brain 2000; 123( Pt 11):2203-2212.

25 Arndt TL, Stodgell CJ, Rodier PM: The teratology of autism. Int J Dev Neurosci 2005;23: 189-199. 
-26 Herbert MR, Russo JP, Yang S, Roohi J, Blaxill M, Kahler SG, Cremer L, Hatchwell E: Autism and environmental genomics. Neurotoxicology 2006;27:671-684.

-27 Geier DA, Kern JK, Garver CR, Adams JB, Audhya T, Nataf R, Geier MR: Biomarkers of environmental toxicity and susceptibility in autism. J Neurol Sci 2009;280:101-108.

28 Kern JK, Jones AM: Evidence of toxicity, oxidative stress, and neuronal insult in autism. J Toxicol Environ Health B Crit Rev 2006;9: 485-499.

29 Libbey JE, Sweeten TL, McMahon WM, Fujinami RS: Autistic disorder and viral infections. J Neurovirol 2005;11:1-10.

-30 Ghaziuddin M: A family history study of Asperger syndrome. J Autism Dev Disord 2005; 35:177-182.

-31 Carroll LS, Owen MJ: Genetic overlap between autism, schizophrenia and bipolar disorder. Genome Med 2009;1:102.

-32 Burbach JP, van der Zwaag B: Contact in the genetics of autism and schizophrenia. Trends Neurosci 2009;32:69-72.

33 Chan RC, Di X, McAlonan GM, Gong QY: Brain anatomical abnormalities in highrisk individuals, first-episode, and chronic schizophrenia: an activation likelihood estimation meta-analysis of illness progression. Schizophr Bull 2009, E-pub ahead of print.

34 Cheung C, Yu KK, Fung G, Leung MK, Wong C, Li Q, Sham PC, Chua SE, McAlonan GM: Autistic disorders and schizophrenia: related or remote? An anatomical likelihood estimation. PLoS ONE 2010, under revision.

- 35 Cheung V, Cheung C, McAlonan GM, Deng Y, Wong JG, Yip L, Tai KS, Khong PL, Sham P, Chua SE: A diffusion tensor imaging study of structural dysconnectivity in never-medicated, first-episode schizophrenia. Psychol Med 2008;38:877-885.

- 36 Chua SE, Cheung C, Cheung V, Tsang JT, Chen EY, Wong JC, Cheung JP, Yip L, Tai KS, Suckling J, McAlonan GM: Cerebral grey, white matter and CSF in never-medicated, first-episode schizophrenia. Schizophr Res 2007;89:12-21.

-37 Chua SE, Deng Y, Chen EY, Law CW, Chiu $\mathrm{CP}$, Cheung C, Wong JC, Lienenkaemper N, Cheung V, Suckling J, McAlonan GM: Early striatal hypertrophy in first-episode psychosis within 3 weeks of initiating antipsychotic drug treatment. Psychol Med 2009;39:793800.

38 Leung M, Cheung C, Yu K, Yip B, Sham P, Li Q, Chua S, McAlonan G: Gray matter in first-episode schizophrenia before and after antipsychotic drug treatment. Anatomical likelihood estimation meta-analyses with sample size weighting. Schizophr Bulletin 2009, E-pub ahead of print.

-39 Toal F, Bloemen OJ, Deeley Q, Tunstall N, Daly EM, Page L, Brammer MJ, Murphy KC, Murphy DG: Psychosis and autism: magnetic resonance imaging study of brain anatomy. Br J Psychiatry 2009;194:418-425.
40 Craig JS, Hatton C, Craig FB, Bentall RP: Persecutory beliefs, attributions and theory of mind: comparison of patients with paranoid delusions, Asperger's syndrome and healthy controls. Schizophr Res 2004;69:2933.

41 Rausch JL, Sirota EL, Londino DL, Johnson ME, Carr BM, Bhatia R, Miller S: Open-label risperidone for Asperger's disorder: negative symptom spectrum response. J Clin Psychiatry 2005;66:1592-1597.

- 42 McDougle CJ, Stigler KA, Erickson CA, Posey DJ: Atypical antipsychotics in children and adolescents with autistic and other pervasive developmental disorders. J Clin Psychiatry 2008;69(Suppl 4):15-20.

43 Posey DJ, Stigler KA, Erickson CA, McDougle CJ: Antipsychotics in the treatment of autism. J Clin Invest 2008;118:6-14.

\$4 Perry W, Minassian A, Lopez B, Maron L, Lincoln A: Sensorimotor gating deficits in adults with autism. Biol Psychiatry 2007;61: $482-486$.

-45 Kumari V, Fannon D, Geyer MA, Premkumar P, Antonova E, Simmons A, Kuipers E: Cortical grey matter volume and sensorimotor gating in schizophrenia. Cortex $2008 ; 44$ : 1206-1214.

46 Braff DL, Geyer MA, Swerdlow NR: Human studies of prepulse inhibition of startle: Normal subjects, patient groups, and pharmacological studies. Psychopharmacology 2001; 156:234-258.

47 Esterberg ML, Trotman HD, Brasfield JL, Compton MT, Walker EF: Childhood and current autistic features in adolescents with schizotypal personality disorder. Schizophr Res 2008;104:265-273.

48 van Os J, Kapur S: Schizophrenia. Lancet 2009;374:635-645.

49 Crespi B, Badcock C: Psychosis and autism as diametrical disorders of the social brain. Behav Brain Sci 2008;31:241-261, discussion 261-320.

50 Ornitz EM, Lane SJ, Sugiyama T, de Traversay J: Startle modulation studies in autism. J Autism Dev Disord 1993;23:619-637.

51 Swerdlow NR, Benbow CH, Zisook S, Geyer MA, Braff DL: A preliminary assessment of sensorimotor gating in patients with obsessive compulsive disorder. Biol Psychiatry 1993;33:298-301.

52 Light GA, Braff DL: Human and animal studies of schizophrenia-related gating deficits. Curr Psychiatry Rep 1999;1:31-40.

53 Swerdlow NR, Braff DL, Geyer MA: Animal models of deficient sensorimotor gating: What we know, what we think we know, and what we hope to know soon. Behav Pharmacol 2000;11:185-204.

54 Swerdlow NR, Braff DL, Taaid N, Geyer MA: Assessing the validity of an animal model of deficient sensorimotor gating in schizophrenic patients. Arch Gen Psychiatry 1994; 51:139-154.
55 Swerdlow NR, Weber M, Qu Y, Light GA, Braff DL: Realistic expectations of prepulse inhibition in translational models for schizophrenia research. Psychopharmacology 2008;199:331-388.

56 Moy SS, Nadler JJ: Advances in behavioral genetics: mouse models of autism. Mol Psychiatry 2008;13:4-26.

57 Moy SS, Nadler JJ, Young NB, Perez A, Holloway LP, Barbaro RP, Barbaro JR, Wilson LM, Threadgill DW, Lauder JM, Magnuson TR, Crawley JN: Mouse behavioral tasks relevant to autism: phenotypes of 10 inbred strains. Behav Brain Res 2007;176:4-20.

58 Yerys BE, Wallace GL, Harrison B, Celano MJ, Giedd JN, Kenworthy LE: Set-shifting in children with autism spectrum disorders: reversal shifting deficits on the intradimensional/extradimensional shift test correlate with repetitive behaviors. Autism 2009;13: 523-538.

59 Crider A: Perseveration in schizophrenia. Schizophr Bull 1997;23:63-74.

60 Lanser MG, Berger HJ, Ellenbroek BA, Cools AR, Zitman FG: Perseveration in schizophrenia: failure to generate a plan and relationship with the psychomotor poverty subsyndrome. Psychiatry Res 2002;112:13-26.

61 Brown AS: Prenatal infection as a risk factor for schizophrenia. Schizophr Bull 2006;32: 200-202.

62 Brown AS, Begg MD, Gravenstein S, Schaefer CA, Wyatt RJ, Bresnahan M, Babulas VP, Susser ES: Serologic evidence of prenatal influenza in the etiology of schizophrenia. Arch Gen Psychiatry 2004;61:774-780.

-63 Brown AS, Schaefer CA, Quesenberry CP Jr, Liu L, Babulas VP, Susser ES: Maternal exposure to toxoplasmosis and risk of schizophrenia in adult offspring. Am J Psychiatry 2005; 162:767-773.

64 Chess S: Autism in children with congenital rubella. J Autism Child Schizophr 1971;1: 33-47.

65 Chess S: Follow-up report on autism in congenital rubella. Journal of autism and childhood schizophrenia 1977;7:69-81.

66 Chess S, Fernandez P, Korn S: Behavioral consequences of congenital rubella. J Pediatr 1978;93:699-703

67 Yamashita Y, Fujimoto C, Nakajima E, Isagai T, Matsuishi T: Possible association between congenital cytomegalovirus infection and autistic disorder. J Autism and Dev Disord 2003;33:455-459.

68 Ciaranello AL, Ciaranello RD: The neurobiology of infantile autism. Annu Rev Neurosci 1995; 18:101-128.

69 Lipkin WI, Hornig M: Microbiology and immunology of autism spectrum disorders. Novartis Found Symp 2003;251:129-143, discussion 144-128, 281-197.

-70 Fatemi SH, Cuadra AE, El-Fakahany EE, Sidwell RW, Thuras P: Prenatal viral infection causes alterations in nNOS expression in developing mouse brains. Neuroreport 2000;11:1493-1496. 
-71 Fatemi SH, Earle J, Kanodia R, Kist D, Emamian ES, Patterson PH, Shi L, Sidwell R: Prenatal viral infection leads to pyramidal cell atrophy and macrocephaly in adulthood: implications for genesis of autism and schizophrenia. Cell Mol Neurobiol 2002;22: 25-33.

-72 Hornig M, Briese T, Lipkin WI: Bornavirus tropism and targeted pathogenesis: virushost interactions in a neurodevelopmental model. Adv Virus Res 2001;56:557-582.

-73 Hornig M, Solbrig M, Horscroft N, Weissenbock H, Lipkin WI: Borna disease virus infection of adult and neonatal rats: models for neuropsychiatric disease. Curr Top Microbiol Immunol 2001;253:157-177.

- 74 Hornig M, Weissenbock H, Horscroft N, Lipkin WI: An infection-based model of neurodevelopmental damage. Proc Natl Acad Sci USA 1999;96:12102-12107.

-75 Lancaster K, Dietz DM, Moran TH, Pletnikov MV: Abnormal social behaviors in young and adult rats neonatally infected with borna disease virus. Behav Brain Res 2007;176:141-148.

-76 Shi L, Fatemi SH, Sidwell RW, Patterson PH: Maternal influenza infection causes marked behavioral and pharmacological changes in the offspring. J Neurosci 2003;23:297-302.

77 Shi L, Smith SE, Malkova N, Tse D, Su Y, Patterson PH: Activation of the maternal immune system alters cerebellar development in the offspring. Brain Behav Immun 2009; 23:116-123.

-78 Amaral DG, Schumann CM, Nordahl CW: Neuroanatomy of autism. Trends Neurosci 2008;31:137-145.

-79 Maloku E, Covelo IR, Hanbauer I, Guidotti A, Kadriu B, Hu Q, Davis JM, Costa E: Lower number of cerebellar Purkinje neurons in psychosis is associated with reduced reelin expression. Proc Natl AcadSci USA 2010;107: 4407-4411.

-80 Fatemi SH, Emamian ES, Kist D, Sidwell RW, Nakajima K, Akhter P, Shier A, Sheikh S, Bailey K: Defective corticogenesis and reduction in reelin immunoreactivity in cortex and hippocampus of prenatally infected neonatal mice. Mol Psychiatry 1999;4:145-154.

-81 Fatemi SH, Earle JA, McMenomy T: Reduction in reelin immunoreactivity in hippocampus of subjects with schizophrenia, bipolar disorder and major depression. Mol Psychiatry 2000;5:654-663, 571.

-82 Fatemi SH, Snow AV, Stary JM, AraghiNiknam M, Reutiman TJ, Lee S, Brooks AI, Pearce DA: Reelin signaling is impaired in autism. Biol Psychiatry 2005;57:777-787.

-83 Fatemi SH, Stary JM, Egan EA: Reduced blood levels of reelin as a vulnerability factor in pathophysiology of autistic disorder. Cell Mol Neurobiol 2002;22:139-152.

-84 Fatemi SH, Stary JM, Halt AR, Realmuto GR: Dysregulation of Reelin and $\mathrm{Bcl}-2$ proteins in autistic cerebellum. J Autism Dev Disord 2001;31:529-535.
Guidotti A, Auta J, Davis JM, Di-Giorgi-Gerevini V, Dwivedi Y, Grayson DR, Impagnatiello F, Pandey G, Pesold C, Sharma R, Uzunov D, Costa E: Decrease in reelin and glutamic acid decarboxylase 67 (GAD67) expression in schizophrenia and bipolar disorder: a postmortem brain study. Arch Gen Psychiatry 2000;57:1061-1069.

86 Fatemi SH, Pearce DA, Brooks AI, Sidwell RW: Prenatal viral infection in mouse causes differential expression of genes in brains of mouse progeny: a potential animal model for schizophrenia and autism. Synapse 2005;57: 91-99.

87 Fatemi SH, Folsom TD, Reutiman TJ, AbuOdeh D, Mori S, Huang H, Oishi K: Abnormal expression of myelination genes and alterations in white matter fractional anisotropy following prenatal viral influenza infection at E16 in mice. Schizophr Res 2009; 112:46-53.

88 Li Q, Cheung C, Wei R, Hui ES, Feldon J, Meyer U, Chung S, Chua SE, Sham PC, Wu EX, McAlonan GM: Prenatal immune challenge is an environmental risk factor for brain and behavior change relevant to schizophrenia: evidence from MRI in a mouse model. PLoS ONE 2009;4:e6354.

-89 Meyer U, Engler A, Weber L, Schedlowski M, Feldon J: Preliminary evidence for a modulation of fetal dopaminergic development by maternal immune activation during pregnancy. Neuroscience 2008;154:701-709.

90 Meyer U, Feldon J, Schedlowski M, Yee BK: Immunological stress at the maternal-foetal interface: A link between neurodevelopment and adult psychopathology. Brain, behavior, and immunity 2006;20:378-388.

91 Meyer U, Feldon J, Schedlowski M, Yee BK: Towards an immuno-precipitated neurodevelopmental animal model of schizophrenia. Neurosci Biobehav Rev 2005;29:913-947.

92 Meyer U, Murray PJ, Urwyler A, Yee BK, Schedlowski M, Feldon J: Adult behavioral and pharmacological dysfunctions following disruption of the fetal brain balance between pro-inflammatory and IL-10-mediated anti-inflammatory signaling. Mol Psychiatry 2008; $13: 208-221$.

\$3 Meyer U, Nyffeler M, Engler A, Urwyler A, Schedlowski M, Knuesel I, Yee BK, Feldon J: The time of prenatal immune challenge determines the specificity of inflammationmediated brain and behavioral pathology. J Neurosci 2006;26:4752-4762.

94 Meyer U, Nyffeler M, Schwendener S, Knuesel I, Yee BK, Feldon J: Relative prenatal and postnatal maternal contributions to schizophrenia-related neurochemical dysfunction after in utero immune challenge. Neuropsychopharmacology 2008;33:441-456.

95 Meyer U, Nyffeler M, Yee BK, Knuesel I, Feldon J: Adult brain and behavioral pathological markers of prenatal immune challenge during early/middle and late fetal development in mice. Brain Behav Immun 2008;22: 469-486.
96 Meyer U, Schwendener S, Feldon J, Yee BK: Prenatal and postnatal maternal contributions in the infection model of schizophrenia. Exp Brain Res 2006;173:243-257.

$\$ 97$ Meyer U, Yee BK, Feldon J: The neurodevelopmental impact of prenatal infections at different times of pregnancy: the earlier the worse? Neuroscientist 2007;13:241-256.

\$8 Nyffeler M, Meyer U, Yee BK, Feldon J, Knuesel I: Maternal immune activation during pregnancy increases limbic GABAA receptor immunoreactivity in the adult offspring: Implications for schizophrenia. Neuroscience 2006;143:51-62.

99 Makinodan M, Tatsumi K, Manabe T, Yamauchi T, Makinodan E, Matsuyoshi $\mathrm{H}$ Shimoda S, Noriyama Y, Kishimoto T, Wanaka A: Maternal immune activation in mice delays myelination and axonal development in the hippocampus of the offspring. J Neurosci Res 2008;86:2190-2200.

100 Li Q, Cheung C, Wei R, Cheung V, Hui ES, You Y, Wong P, Chua SE, McAlonan GM, Wu EX: Voxel-based analysis of postnatal white matter microstructure in mice exposed to immune challenge in early or late pregnancy. Neuroimage 2010;52:1-8.

101 Smith SE, Li J, Garbett K, Mirnics K, Patterson PH: Maternal immune activation alters fetal brain development through interleukin-6. J Neurosci 2007;27:10695-10702.

102 Ponzio NM, Servatius R, Beck K, Marzouk A, Kreider T: Cytokine levels during pregnancy influence immunological profiles and neurobehavioral patterns of the offspring. Ann NY Acad Sci 2007;1107:118128.

103 Hama T, Kushima Y, Miyamoto M, Kubota M, Takei N, Hatanaka H: Interleukin-6 improves the survival of mesencephalic catecholaminergic and septal cholinergic neurons from postnatal, two-week-old rats in cultures. Neuroscience 1991;40:445-452.

104 Hama T, Miyamoto M, Tsukui H, Nishio C, Hatanaka $\mathrm{H}$ : Interleukin-6 as a neurotrophic factor for promoting the survival of cultured basal forebrain cholinergic neurons from postnatal rats. Neurosci Lett 1989;104:340-344.

105 Pratt L, Ponzio NM, Ni L, Sheng I, Jonakait GM: Fetal microglia become activated following maternal immune challenge. IMFAR 2010.

106 Vuillermot S, Weber L, Feldon J, Meyer U: A longitudinal examination of the neurodevelopmental impact of prenatal immune activation in mice reveals primary defects in dopaminergic development relevant to schizophrenia. J Neurosci 2010;30:12701287.

107 Ulfig N, Friese K: Interleukin-6 receptor is highly expressed in the ganglionic eminence of the human fetal brain. Biol Neonate 1999;76:320-324.

108 Ulfig N: Ganglionic eminence of the human fetal brain - new vistas. Anat Rec 2002;267:191-195. 
109 Beltinger C, Saule H: Sonography of subep- 122 Monji A, Kato T, Kanba S: Cytokines and endymal cysts in congenital rubella syndrome. Eur J Pediatr 1988;148:206-207.

110 Borrell J, Vela JM, Arevalo-Martin A, Molina-Holgado E, Guaza C: Prenatal immune challenge disrupts sensorimotor gating in adult rats. Implications for the etiopathogenesis of schizophrenia. Neuropsychopharmacology 2002;26:204-215.

-111 Fortier ME, Luheshi GN, Boksa P: Effects of prenatal infection on prepulse inhibition in the rat depend on the nature of the infectious agent and the stage of pregnancy. Behav Brain Res 2007;181:270-277.

112 Golan HM, Lev V, Hallak M, Sorokin Y, Huleihel M: Specific neurodevelopmental damage in mice offspring following maternal inflammation during pregnancy. Neuropharmacology 2005;48:903-917.

- 113 Fidel PL Jr, Romero R, Wolf N, Cutright J, Ramirez M, Araneda H, Cotton DB: Systemic and local cytokine profiles in endotoxin-induced preterm parturition in mice. Am J Obstet Gynecol 1994;170:1467-1475.

114 Molloy CA, Morrow AL, Meinzen-Derr J, Schleifer K, Dienger K, Manning-Courtney P, Altaye M, Wills-Karp M: Elevated cytokine levels in children with autism spectrum disorder. J Neuroimmunology 2006; 172:198-205.

-115 Gupta S, Aggarwal S, Rashanravan B, Lee T: Th1- and Th2-like cytokines in CD4+ and CD8+ T cells in autism. J Neuroimmunol 1998;85:106-109.

-116 Pardo CA, Vargas DL, Zimmerman AW: Immunity, neuroglia and neuroinflammation in autism. Int Rev Psychiatry 2005;17: 485-495.

-117 Vargas DL, Nascimbene C, Krishnan C, Zimmerman AW, Pardo CA: Neuroglial activation and neuroinflammation in the brain of patients with autism. Ann Neurol 2005;57:67-81.

-118 Martin LA, Ashwood P, Braunschweig D, Cabanlit M, Van de Water J, Amaral DG: Stereotypies and hyperactivity in rhesus monkeys exposed to IgG from mothers of children with autism. Brain Behav Immun 2008;22:806-816.

- 119 Zimmerman AW, Connors SL, Matteson KJ, Lee LC, Singer HS, Castaneda JA, Pearce DA: Maternal antibrain antibodies in autism. Brain Behav Immun 2007;21:351-357.

-120 Singer HS, Morris C, Gause C, Pollard M, Zimmerman AW, Pletnikov M: Prenatal exposure to antibodies from mothers of children with autism produces neurobehavioral alterations: a pregnant dam mouse model. J Neuroimmunol 2009;211:39-48.

121 Creasy RK, Resnik R, Iams JD, Lockwood CJ, Moore TR (eds): Creasy and Resnik's Maternal-Fetal Medicine: Principles and Practice, ed 6. Saunders/Elsevier Health Sciences 2004, pp 583-584. schizophrenia: microglia hypothesis of schizophrenia. Psychiatry Clin Neurosci 2009;63:257-265.

123 Oppenheim SM, Moyer AL, BonDurant RH, Rowe JD, Anderson GB: Fetal leukocyte trafficking as a stimulus for the production of maternal antibodies in the goat. Theriogenology 2001;55:1583-1591.

124 Goodman HS, Masaitis L: Analysis of the isoimmune response to leucocytes: I. Maternal cytotoxic response to fetal lymphocytes. Proc Soc Exp Biol Med 1967;126: 599-604.

125 O’Callaghan E, Sham P, Takei N, Glover G, Murray RM: Schizophrenia after prenatal exposure to 1957 A2 influenza epidemic. Lancet 1991;337:1248-1250.

-126 Kunugi H, Nanko S, Takei N, Saito K, Hayashi N, Kazamatsuri H: Schizophrenia following in utero exposure to the 1957 influenza epidemics in Japan. Am J Psychiatry 1995;152:450-452.

127 Mednick SA, Huttunen MO, Machon RA: Prenatal influenza infections and adult schizophrenia. Schizophr Bull 1994;20: 263-267.

128 Adams W, Kendell RE, Hare EH, MunkJorgensen P: Epidemiological evidence that maternal influenza contributes to the aetiology of schizophrenia. An analysis of Scottish, English, and Danish data. Br J Psychiatry 1993;163:522-534.

129 Bauman ML, Kemper TL: Neuroanatomic observations of the brain in autism: a review and future directions. Int J Dev Neu-

130 Bailey A, Luthert P, Dean A, Harding B, Janota I, Montgomery M, Rutter M, Lantos P: A clinicopathological study of autism. Brain 1998;121:889-905.

131 BeversdorfDQ, Manning SE, Hillier A, Anderson SL, Nordgren RE, Walters SE, Nagaraja $\mathrm{HN}$, Cooley WC, Gaelic SE, Bauman ML: Timing of prenatal stressors and autism. J Autism Dev Disord 2005;35:471478.

132 Kinney DK, Miller AM, Crowley DJ, Huang E, Gerber E: Autism prevalence following prenatal exposure to hurricanes and tropical storms in Louisiana. J Autism Dev Disord 2008;38:481-488.

133 Atladottir HO, Thorsen P, Ostergaard L, Schendel DE, Lemcke S, Abdallah M, Parner ET: Maternal infection requiring hospitalization during pregnancy and autism spectrum disorders. J Autism Dev Disord 2010, E-pub ahead of print.

134 Clancy B, Darlington RB, Finlay BL: Translating developmental time across mammalian species. Neuroscience 2001;105:7-17.

135 Clancy B, Kersh B, Hyde J, Darlington RB, Anand KJ, Finlay BL: Web-based method for translating neurodevelopment from laboratory species to humans. Neuroinformatics 2007;5:79-94. rosci 2005;23:183-187.
136 Swerdlow NR, Braff DL, Hartston H, Perry W, Geyer MA: Latent inhibition in schizophrenia. Schizophr Res 1996;20:91-103.

137 Geyer MA, Krebs-Thomson K, Braff DL, Swerdlow NR: Pharmacological studies of prepulse inhibition models of sensorimotor gating deficits in schizophrenia: a decade in review. Psychopharmacology 2001;156: 117-154.

138 Nakamura K, Sekine Y, Ouchi Y, Tsujii M, Yoshikawa E, Futatsubashi M, Tsuchiya KJ, Sugihara G, Iwata Y, Suzuki K, Matsuzaki H, Suda S, Sugiyama T, Takei N, Mori N: Brain serotonin and dopamine transporter bindings in adults with high-functioning autism. Arch Gen Psychiatry 2010;67:5968.

139 Nieminen-von Wendt T, Metsahonkala L, Kulomaki TA, Aalto S, Autti TH, Vanhala R, Eskola O, Bergman J, Hietala JA, Von Wendt LO: Increased presynaptic dopamine function in Asperger syndrome. Neuroreport 2004;15:757-760.

140 Hus V, Pickles A, Cook EH Jr, Risi S, Lord $\mathrm{C}$ : Using the autism diagnostic interview revised to increase phenotypic homogeneity in genetic studies of autism. Biol Psychiatry 2007;61:438-448.

141 Fatemi SH, Reutiman TJ, Folsom TD, Huang H, Oishi K, Mori S, Smee DF, Pearce DA, Winter C, Sohr R, Juckel G: Maternal infection leads to abnormal gene regulation and brain atrophy in mouse offspring: implications for genesis of neurodevelopmental disorders. Schizophr Res 2008;99:5670.

142 Fatemi SH, Emamian ES, Sidwell RW, Kist DA, Stary JM, Earle JA, Thuras P: Human influenza viral infection in utero alters glial fibrillary acidic protein immunoreactivity in the developing brains of neonatal mice. Mol Psychiatry 2002;7:633-640.

143 Fatemi SH, Reutiman TJ, Folsom TD, Sidwell RW: The role of cerebellar genes in pathology of autism and schizophrenia. Cerebellum 2008;7:279-294.

144 Sanjuan J, Tolosa A, Gonzalez JC, Aguilar EJ, Perez-Tur J, Najera C, Molto MD, de Frutos R: Association between FOXP2 polymorphisms and schizophrenia with auditory hallucinations. Psychiatr Genet 2006;16:67-72.

145 Gong X, Jia M, Ruan Y, Shuang M, Liu J, Wu S, Guo Y, Yang J, Ling Y, Yang X, Zhang D: Association between the FOXP2 gene and autistic disorder in Chinese population. Am J Med Genet B Neuropsychiatr Genet 2004;127B:113-116.

146 Chua SE, McKenna PJ: Schizophrenia - a brain disease? A critical review of structural and functional cerebral abnormality in the disorder. Br J Psychiatry 1995;166:563582 . 
147 Chua SE, Lam IW, Tai KS, Cheung C, Tang WN, Chen EY, Lee PW, Chan FL, Lieh-Mak F, McKenna PJ: Brain morphological abnormality in schizophrenia is independent of country of origin. Acta Psychiatr Scand 2003;108:269-275.

148 Vidal CN, Nicolson R, Boire JY, Barra V, DeVito TJ, Hayashi KM, Geaga JA, Drost DJ, Williamson PC, Rajakumar N, Toga AW, Thompson PM: Three-dimensional mapping of the lateral ventricles in autism. Psychiatry Res 2008;163:106-115.

149 Winter C, Reutiman TJ, Folsom TD, Sohr R, Wolf RJ, Juckel G, Fatemi SH: Dopamine and serotonin levels following prenatal viral infection in mouse - implications for psychiatric disorders such as schizophrenia and autism. Eur Neuropsychopharmacol 2008;18:712-716.

150 Perry W, Minassian A, Henry B, Kincaid M, Young JW, Geyer MA: Quantifying overactivity in bipolar and schizophrenia patients in a human open field paradigm. Psychiatry Res 2010;178:84-91.

151 Pierce K, Courchesne E: Evidence for a cerebellar role in reduced exploration and stereotyped behavior in autism. Biol Psychiatry 2001;49:655-664.
152 Walter H, Ciaramidaro A, Adenzato M, Vasic N, Ardito RB, Erk S, Bara BG: Dysfunction of the social brain in schizophrenia is modulated by intention type: an fMRI study. Soc Cogn Affect Neurosci 2009;4: 166-176.

153 Williams DL, Goldstein G, Carpenter PA, Minshew NJ: Verbal and spatial working memory in autism. J Autism Dev Disord 2005;35:747-756.

154 Snyder PJ, Jackson CE, Piskulic D, Olver J, Norman T, Maruff P: Spatial working memory and problem solving in schizophrenia: the effect of symptom stabilization with atypical antipsychotic medication. Psychiatry Res 2008;160:316-326.

155 Feldon J, Weiner I: From an animal model of an attentional deficit towards new insights into the pathophysiology of schizophrenia. J Psychiatr Res 1992;26:345-366.

156 Bitanihirwe BK, Peleg-Raibstein D, Mouttet F, Feldon J, Meyer U: Late prenatal immune activation in mice leads to behavioral and neurochemical abnormalities relevant to the negative symptoms of schizophrenia. Neuropsychopharmacology 2010, E-pub ahead of print.
157 Gruzelier J, Thornton S, Staniforth D, Zaki $\mathrm{S}$, Yorkston N: Active and passive avoidance learning in controls and schizophrenic patients on racemic propranolol and neuroleptics. Br J Psychiatry 1980;137:131-137.

158 Deng MY, McAlonan GM, Cheung C, Chiu CP, Law CW, Cheung V, Sham PC, Chen EY, Chua SE: A naturalistic study of grey matter volume increase after early treatment in anti-psychotic naive, newly diagnosed schizophrenia. Psychopharmacology 2009;206:437-446.

159 Honer WG, Falkai P, Chen C, Arango V, Mann JJ, Dwork AJ: Synaptic and plasticityassociated proteins in anterior frontal cortex in severe mental illness. Neuroscience 1999;91:1247-1255.

160 Davis KL, Stewart DG, Friedman JI, Buchsbaum M, Harvey PD, Hof PR, Buxbaum J, Haroutunian V: White matter changes in schizophrenia: evidence for myelin-related dysfunction. Arch Gen Psychiatry 2003;60: 443-456.

161 Singh VK, Warren RP, Odell JD, Warren WL, Cole P: Antibodies to myelin basic protein in children with autistic behavior. Brain Behav Immun 1993;7:97-103. 